\title{
Enhancing Jatropha oil extraction yield from the kernels assisted by a xylan-degrading bacterium to preserve protein structure
}

\author{
Ahmad Marasabessy • Maelita R. Moeis • \\ Johan P. M. Sanders • Ruud A. Weusthuis
}

Received: 10 February 2011 /Revised: 5 April 2011 /Accepted: 5 April 2011 /Published online: 10 May 2011

(C) The Author(s) 2011 This article is published with open access at Springerlink.com

\begin{abstract}
We investigated the use of bacterial cells isolated from paddy crab for the extraction of oil from Jatropha seed kernels in aqueous media while simultaneously preserving the protein structures of this protein-rich endosperm. A bacterial strain - which was marked as MB4 and identified by means of $16 \mathrm{~S}$ rDNA sequencing and physiological characterization as either Bacillus pumilus or Bacillus altitudinis - enhanced the extraction yield of Jatropha oil. The incubation of an MB4 starter culture with preheated kernel slurry in aqueous media with the initial $\mathrm{pH}$ of 5.5 at $37{ }^{\circ} \mathrm{C}$ for $6 \mathrm{~h}$ liberated $73 \% \mathrm{w} / \mathrm{w}$ of the Jatropha oil. Since
\end{abstract}

A. Marasabessy • J. P. M. Sanders · R. A. Weusthuis

Valorisation of Plant Production Chains, Wageningen University,

P.O. Box 17, 6700 AA Wageningen, the Netherlands

\section{A. Marasabessy}

Department of Chemical Engineering,

RijksUniversiteit Groningen,

Nijenborgh 4,

9747 AG Groningen, the Netherlands

\author{
A. Marasabessy \\ Agency for the Assessment \\ and Application of Technology (BPPT), \\ J1. MH Thamrin 8 , \\ Jakarta, Indonesia

\section{R. Moeis} \\ School of Life Sciences and Technology, \\ Institut Teknologi Bandung, \\ Jl. Ganesha 10 , \\ Bandung, Indonesia \\ A. Marasabessy $(\bowtie)$ \\ Agrotechnology and Food Sciences Group, \\ Valorisation of Plant Production Chains, \\ Wageningen University and Research Centre, \\ P.O. Box 17, 6700 AA Wageningen, the Netherlands \\ e-mail: ahmad.marasabessy@wur.nl
}

MB4 produces xylanases, it is suggested that strain MB4 facilitates oil liberation via degradation of hemicelluloses which form the oil-containing cell wall structure of the kernel. After MB4 assisted oil extraction, SDS-PAGE analysis showed that the majority of Jatropha proteins were preserved in the solid phase of the extraction residues. The advantages offered by this process are: protein in the residue can be further processed for other applications, no purified enzyme preparation is needed, and the resulting oil can be used for biodiesel production.

Keywords Jatropha curcas · Aqueous oil extraction · Bacillus pumilus $\cdot$ Bacillus altitudinis $\cdot$ Protease $\cdot$ Xylanase

\section{Introduction}

Jatropha curcas is a well-known plant for the high fat and protein content of its seed ranging between $45 \%$ and $55 \%$ $w / w$ and $20-30 \% w / w$ of the kernels, respectively (Gubitz et al. 1999; Lestari et al. 2010). This oil is economically attractive due to its potential application in biodiesel (Lin et al. 2003; Martinez-Herrera et al. 2006). In addition, the kernel contains $28 \%$ protein, which has been extensively studied for food and non-food application (Gubitz et al. 1999; Lestari et al. 2010; Lin et al. 2003; Martinez-Herrera et al. 2006). Lestari extracted more than $80 \%$ of the protein from the kernels and addressed some potential applications of the isolated protein in various fields such as adhesives, coatings, and chemicals (Lestari et al. 2010). Therefore, with respect to the overall economy of Jatropha cultivation, it is interesting to find a commercial use for both oil and protein. Protein recovery from the kernel requires aqueous extraction; hence, it is interesting to see if aqueous extraction can also be used for the release of oil. 
The common method of oil production from oilseeds as feedstock for biodiesel involves pressing of seeds and oil purification (degumming, deacidification, dewaxing, dephosphorization, dehydration, etc.). These processes, together with esterification/transesterification, contribute to over $70 \%$ of the total biodiesel production costs (Shuit et al. 2010; Zeng et al. 2009).

Aqueous oil extraction (AOE) uses water as medium to facilitate oil liberation from oilseeds. AOE eliminates organic solvent consumption and so improves process economy (Barrios et al. 1990; Rosenthal et al. 1996). AOE also enables several purification steps such as degumming, deacidification, dewaxing, and dephosphorization to be carried out simultaneously within the extraction step (Caragay 1983) resulting in a more efficient process.

We demonstrated earlier that thermophilic strains isolated from the gut of paddy crabs, one of which was identified as Bacillus licheniformis, enhanced oil liberation up to $60 \%$ from aqueous $J$. curcas kernel, most likely via protein degradation (Marasabessy et al. 2010), which would be disadvantageous for protein recovery. In the present report, we confirmed that these thermophilic bacteria degraded extracted $J$. curcas protein. We also examined if preheating the kernels degraded the proteins in comparison to non-heated kernels by using SDS-PAGE analysis. Next, isolation and selection of mesophilic bacteria from the gut of paddy crabs were performed based on their ability to liberate oil from $J$. curcas preheated kernel slurry. The aim was to obtain other microorganisms able to liberate oil without affecting the protein structures. The best strain was used for aqueous oil extraction from $J$. curcas kernel. The molecular weight distribution of protein in the residue (water phase and solid phase) after microbial treatment was also investigated to examine protein integrity. The quality of recovered oil was analyzed and compared with those of standard values of feedstock for biodiesel.

\section{Materials and methods}

\section{Materials}

Jatropha seeds were harvested from $J$. curcas planted in Serpong, Indonesia (geocoordinates $6^{\circ} 21^{\prime} 31^{\prime \prime} \mathrm{S}, 106^{\circ} 40^{\prime}$ $\left.33^{\prime \prime} \mathrm{E}\right)$. Kernels were obtained after removal of the shells. The sun-dried kernels were stored at $4{ }^{\circ} \mathrm{C}$ until used. Paddy crabs were collected from bunds of a paddy field located in Pamulang, Indonesia (geocoordinates $6^{\circ} 20^{\prime} 52^{\prime \prime} \mathrm{S}, 106^{\circ} 42^{\prime}$ $20^{\prime \prime}$ E). All chemical reagents, unless otherwise specified, were of analytical grade.

\section{J. curcas kernels slurry preparation}

The kernels $(500 \mathrm{~g})$ were autoclaved at $121^{\circ} \mathrm{C}$ for $15 \mathrm{~min}$ and then dried at $60{ }^{\circ} \mathrm{C}$ overnight. The kernels were milled and sieved through a strainer with $1.0 \mathrm{~mm}$ pore diameter. To prepare the preheated kernel slurry, $25 \mathrm{~g}$ milled kernel was homogenized with $125 \mathrm{~g}$ purified water (milli-Q) for $5 \mathrm{~min}$ using a Waring Blender. The weight ratio of solid material to water in the slurry was 1:5. Under constant stirring - to keep the slurry homogenous - $12 \mathrm{~g}$ of kernel slurry (equivalent to $2 \mathrm{~g}$ kernel) was used for the extraction of oil.

Protein extractions from kernels

Protein extraction was carried out by extracting $1 \mathrm{~g}$ of sample with $30 \mathrm{ml}$ solvent for $30 \mathrm{~min}$ in $50 \mathrm{ml}$ capped centrifuge tubes. The mixing was conducted at room temperature by using a rotary mixer. The extracting solvents were water, $\mathrm{NaCl} 1.0 \mathrm{M}$, and $\mathrm{NaOH} 0.055 \mathrm{M}$ as described previously (Lestari et al. 2010). Solid-liquid separation was conducted at $4,000 \times g$ for $15 \mathrm{~min}$ by using a SORVALL6+ centrifuge.

Evaluation of protein degradation by paddy crab bacteria

A mixture of $15 \mathrm{~g} / \mathrm{L}$ Agar-agar (Merck) and $10 \mathrm{~g} / \mathrm{L}$ of $J$. curcas seed protein having a purity of ca. $83 \% \mathrm{w} / \mathrm{w}$ or $10.0 \mathrm{~g} / \mathrm{L}$ of casein (Merck) in water was boiled to dissolve agar. After autoclaving $\left(121^{\circ} \mathrm{C}, 15 \mathrm{~min}\right), 15 \mathrm{ml}$ proteinagar solution was aseptically poured in a sterile petri dish and brought to solidify overnight. The wells in protein-agar media were made by using a sterile rubber cork having a diameter of $9 \mathrm{~mm}$. Two milliliters of a 24-h old bacterial starter culture was centrifuged at 20,000 rpm for $5 \mathrm{~min}$. The supernatant was filtered through a $0.22-\mu \mathrm{m}$ bacterial filter (Millipore), after which $50 \mu \mathrm{l}$ of the filtrate (bacterial crude extract) was pipetted into the well. The plates were placed at $4{ }^{\circ} \mathrm{C}$ overnight to let the extract absorb into the protein-agar media, followed by incubation at $37^{\circ} \mathrm{C}$ for $6 \mathrm{~h}$ and at $45^{\circ} \mathrm{C}$ for $6 \mathrm{~h}$. Clear zones surrounding the well indicating protein solubilization (degradation) by bacterial proteases were observed. A thermostable bacterial neutral protease from Bacillus thermoproteolyticus (Protex 14 L, Genencor) at 200x dilution was used as the positive control, while the preheated bacterial crude extracts and preheated Protex $14 \mathrm{~L}\left(100{ }^{\circ} \mathrm{C}\right.$, $10 \mathrm{~min}$ ), respectively, were used as negative controls.

Jatropha oil extraction by paddy crab paste

The crab paste was prepared as described previously (Marasabessy et al. 2010). To extract oil, $2.0 \mathrm{~g}$ of crab paste was mixed with $30.0 \mathrm{~g}$ of kernel slurry and incubated 
in a orbital shaker at $37{ }^{\circ} \mathrm{C}, 150 \mathrm{rpm}$ for $24 \mathrm{~h}$. Antibiotics were applied in some samples as described previously and the extracted oil was assayed gravimetrically (Marasabessy et al. 2010).

Isolation of mesophilic bacteria from paddy crabs

For the isolation of bacteria, one loop of crab paste was streaked out aseptically on a nutrient agar (NA) medium plate (Merck) and incubated at $37{ }^{\circ} \mathrm{C}$ for $24 \mathrm{~h}$. Well separated colonies were picked up, subcultured, and maintained on NA slants $\left(37^{\circ} \mathrm{C}\right.$ for $\left.24 \mathrm{~h}\right)$.

Selection of mesophilic bacteria for Jatropha oil extraction

Under constant stirring, $12 \mathrm{~g}$ of preheated kernel slurry (equivalent to $2 \mathrm{~g}$ kernel) was weighed out in a $100-\mathrm{ml}$ flask. This was inoculated with $2 \mathrm{ml}$ bacterial suspension, prepared by suspending cells of a bacterial culture grown on an NA agar slant (in a tube having $1.5 \mathrm{~cm}$ diameter and $12 \mathrm{~cm}$ length) with $2 \mathrm{ml}$ sterile water. The mixture was incubated at $37{ }^{\circ} \mathrm{C}$ and $150 \mathrm{rpm}$ for $24 \mathrm{~h}$ using an Innova 44 Incubator Shaker (New Brunswick), after which it was centrifuged at $7,400 \times g$ for $15 \mathrm{~min}$. The extracted oil was assayed gravimetrically (Marasabessy et al. 2010). Control experiments were performed using exactly the same treatment, however without bacterial inoculation. A bacterial strain showing the best performance was identified by partial sequence of $16 \mathrm{~S}$ rDNA as well as physiological tests conducted by DSMZ (Germany).

Microbial Jatropha oil extraction

Bacterial starter culture was prepared as described previously (Marasabessy et al. 2010), except that the nutrient broth medium (NB, Merck) was initially supplemented with $1.0 \%$ $w / v$ milled Jatropha kernel before autoclaving. To extract the oil, $12.0 \mathrm{~g}$ of Jatropha kernel slurry was inoculated with $1.0 \mathrm{ml}$ of the bacterial starter culture. Antibiotics were applied in some samples as described previously (Marasabessy et al. 2010). The mixture was shaken at $150 \mathrm{rpm}$ and $37{ }^{\circ} \mathrm{C}$. After incubation, the slurry was centrifuged at $7,400 \times g$ for $15 \mathrm{~min}$. The free oil on the surface of the liquid in the centrifuge tube was assayed gravimetrically as reported previously (Marasabessy et al. 2010).

Detection of xylanase and glucanase activity in bacterial crude extracts

For xylanase detection, $15 \mu \mathrm{l}$ bacterial crude extract was pipetted into a well (5 $\mathrm{mm}$ diameter) in an agar plate containing 0.2\% Remazol Brilliant Blue Xylan (RBB-Xylan,
Sigma) (Strauss et al. 2001). For cellulose detection, $50 \mu \mathrm{l}$ bacterial crude extract was pipetted into a well $(9 \mathrm{~mm}$ diameter) in an agar plate containing $0.4 \%$ carboxymethyl cellulose (CMC). The plates were placed at $4{ }^{\circ} \mathrm{C}$ overnight to let the extract absorb into the agar media, followed by incubation at $37{ }^{\circ} \mathrm{C}$ for $6 \mathrm{~h}$ (RBB-Xylan agar) and $48 \mathrm{~h}$ (CMC agar). The CMC agar plate was stained with $0.03 \%$ Congo Red, followed by destaining with $1 \mathrm{M} \mathrm{HCl}$ (Teather and Wood 1982). The clear zones surrounding the well indicate the hydrolysis of xylan and cellulose.

\section{SDS-PAGE analysis}

Molecular weight distribution of proteins was analyzed by using SDS-PAGE (NuPage Electrophoresis System with NuPage Novex Bis-Tris Gels 10\% from Invitrogen).

Assay of total oil content, oil yield, and oil quality

The total oil content of the oilseeds was determined by Soxhlet method (AOAC 1984). The total oil content was $0.47 \mathrm{~kg} / \mathrm{kg}$ Jatropha kernels. This amount was taken as $100 \%$ recovery of oil in the calculations of Jatropha oil yield in the extraction experiments. The free fatty acid and moisture content of the extracted oil was assayed by the titration method and the Karl Fischer method, respectively (AOAC 2002). The oxidative stability index (OSI) was assayed using 873 Biodiesel Rancimat apparatus from Metrohm.

\section{Results}

The effect of thermophilic crab bacteria on Jatropha protein integrity

In our previous publication, some thermophilic bacteria (namely BK21, BK22, and B. licheniformis strain BK23 isolated from paddy crabs) extracted up to $60 \%$ of the Jatropha oil from non-heated kernels after $24 \mathrm{~h}$ incubation at $50{ }^{\circ} \mathrm{C}$ under non-optimized conditions (Marasabessy et al. 2010). From the protein-agar plate experiment (Fig. 1), we found that those strains hydrolyzed both $J$. curcas kernel protein and casein upon incubation at $50{ }^{\circ} \mathrm{C}$. BK21 showed the highest protease activity and B. licheniformis BK23 the lowest, as indicated by the size of the clearing zone diameter, for both types of protein. The bright clear zones proved that proteins available in the kernel were completely solubilized.

The effect of heat pretreatment on Jatropha protein integrity

Because we wanted to study the effect of crab's gut bacteria working at lower temperature on the extraction yield of oil 

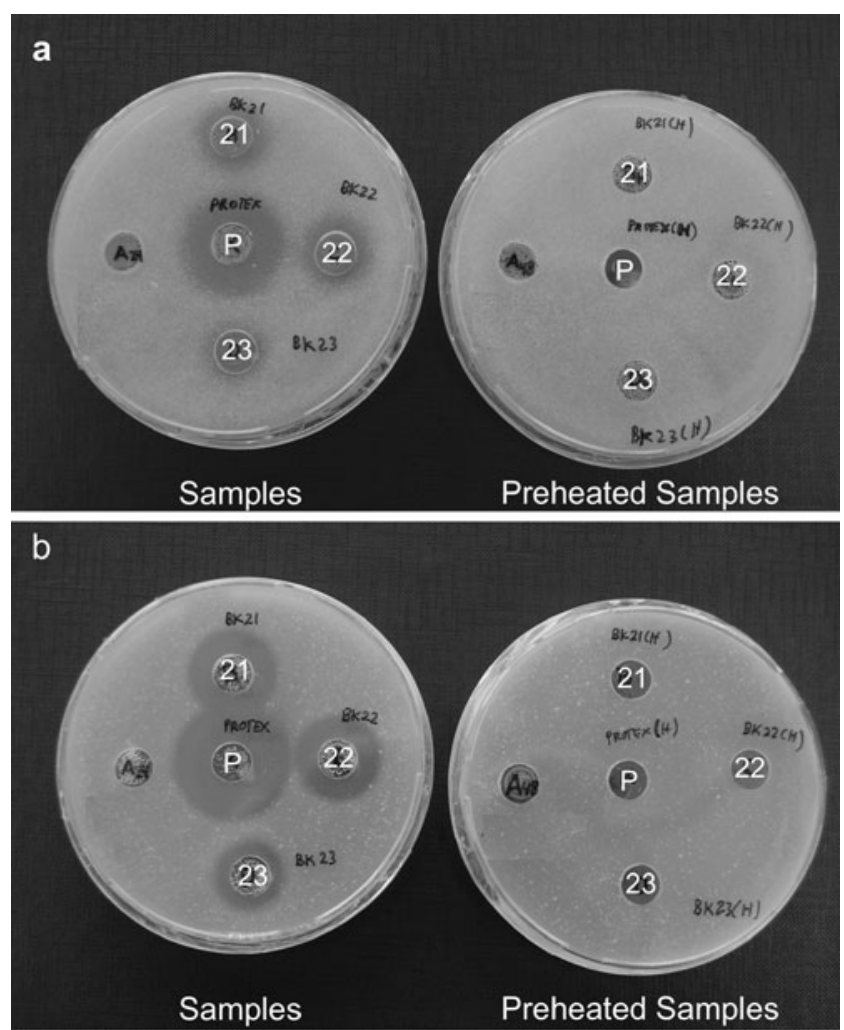

Fig. 1 Protein degradation ability of thermophilic bacterial crude extract of BK21, BK22, B. licheniformis strain BK23 on (a) Jatropha protein agar medium and (b) casein agar medium. These strains were isolated from paddy crabs (Marasabessy et al. 2010). A 200x dilution of Protex $14 \mathrm{~L}$ from Genencor $(P)$ was the positive control. The preheated samples $\left(100{ }^{\circ} \mathrm{C}, 10 \mathrm{~min}\right)$ were the negative controls (showing no clear zone)

from $J$. curcas kernels, internal factors within the kernels influencing oil liberation had to be minimized. Since the kernels contain microorganisms as well as seed enzymes which might interfere with the crab bacteria involved in oil liberation, we applied two different heat pretreatments on kernels, at $105{ }^{\circ} \mathrm{C}$ or $121{ }^{\circ} \mathrm{C}$ for $30 \mathrm{~min}$, to deactivate enzymes and to kill microorganisms before being used for oil extraction. The proteins were extracted from the kernels and the extracts were subjected to SDS-PAGE analysis (Fig. 2). The solubility of proteins in water depends on various factors such as ionic strength and $\mathrm{pH}$; therefore, $1 \mathrm{M} \mathrm{NaCl}$ and $0.055 \mathrm{M} \mathrm{NaOH}$ were also used as extractants besides water (Lestari et al. 2010). The protein pattern of the heat-treated kernels extracted with $\mathrm{NaCl}$ and $\mathrm{NaOH}$ was identical with that of the untreated kernels, showing that heat treatment at both 105 and $121{ }^{\circ} \mathrm{C}$ for $30 \mathrm{~min}$ did not affect the protein composition. Compared to the other samples, the untreated sample extracted with water is missing three small bands at molecular weights of approximately 20 , 23 , and $25 \mathrm{kDa}$, indicating that heat treatment increased the water solubility of the proteins.
Concluding, heat pretreatment did not have an effect on position and relative intensity of the different protein bands on the SDS-PAGE, indicating that no significant alteration of the chemical structures of the proteins occurred. We decided therefore to employ preheated kernels (by autoclaving at $121{ }^{\circ} \mathrm{C}$ for $15 \mathrm{~min}$ ) for oil extraction in the subsequent experiments.

\section{Effect of paddy crab paste on oil extraction}

The presence of mesophilic bacteria in paddy crabs having a positive effect on Jatropha oil liberation was determined by incubating $2 \mathrm{~g}$ paddy crab paste with $30 \mathrm{~g}$ preheated kernel slurry (containing $5 \mathrm{~g}$ kernel) at $37{ }^{\circ} \mathrm{C}$ and $150 \mathrm{rpm}$ for $24 \mathrm{~h}$ with and without addition of antibiotics (Fig. 3). Oil extraction in control experiments to which no crab paste was added resulted in 7\% oil after $24 \mathrm{~h}$. Addition of antibiotics to control samples also gave a low oil yield (4\%). Incubation of preheated kernel slurry with crab paste and antibiotics significantly improved the oil yield to $62 \%$. It is evident that paddy crab paste exhibits a strong effect towards oil liberation from Jatropha kernel. Furthermore, it was shown that excluding antibiotics from the crab-kernel

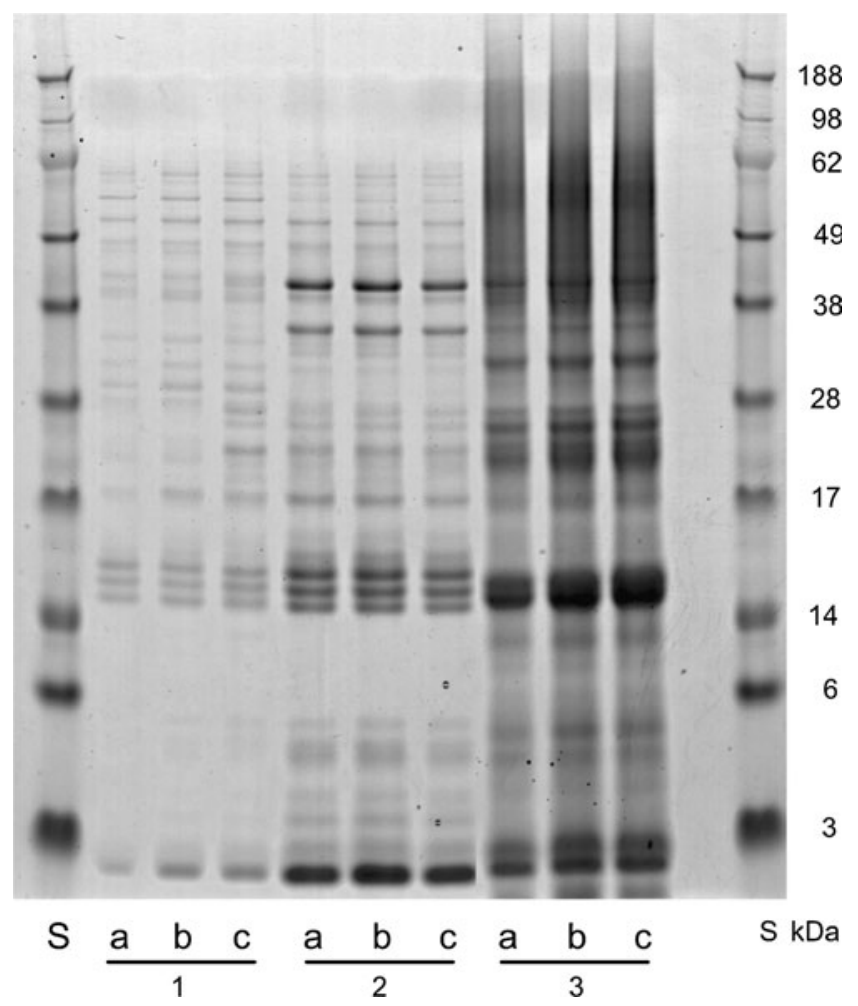

Fig. 2 SDS-PAGE analysis of Jatropha kernel proteins. Bands of proteins from Jatropha kernel showing molecular weight distribution after protein extraction from Jatropha kernel using (1) water, (2) $1.0 \mathrm{M} \mathrm{NaCl}$, and (3) $0.055 \mathrm{M} \mathrm{NaOH}$ with different pretreatment: (a) non-heated, (b) preheated at $105{ }^{\circ} \mathrm{C}$ for $30 \mathrm{~min}$, and (c) $121{ }^{\circ} \mathrm{C}$ for $30 \mathrm{~min}$ 


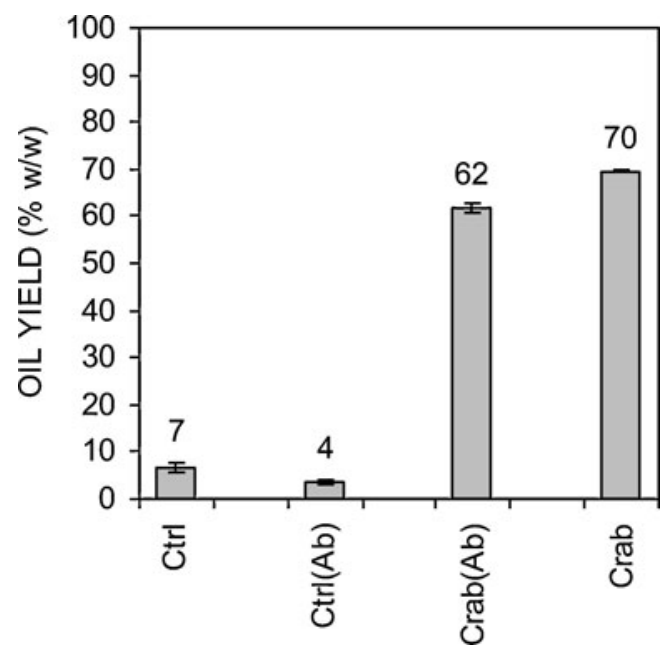

Fig. 3 Jatropha oil extraction yield from preheated kernel slurry incubated with paddy crab paste at $37^{\circ} \mathrm{C}, 150 \mathrm{rpm}$ for $24 \mathrm{~h}$ in comparison to control samples. $\mathrm{Ctrl}=$ control samples; $\mathrm{Ab}=$ antibiotics

sample resulted in even higher oil liberation $(70 \%)$. The significant yield improvement from $62 \%$ to $70 \%$ indicates that mesophilic bacteria derived from paddy crabs take part in the entire mechanism of Jatropha oil liberation from preheated kernel. Based on these results, we decided to isolate mesophilic bacteria living in the gut of paddy crabs as our experimental strains for microbial Jatropha oil extraction.

Protease, xylanase, and glucanase activity of bacterial crude extract

We isolated 20 colonies of mesophilic crab bacteria, but we selected only seven colonies for further testing, namely strains MB4, MB5, MB7, MB11, MB12, MB13, and MB20 based on differences in colony form and microscopic observation. The detection of protease activity in crude extract revealed that MB4 is the only strain exhibiting protease, with different strengths of activity against the two types of protein tested: casein and $J$. curcas protein (Fig. 4a, b). The MB4 protease showed strong activity against casein as shown by a bright clear zone in the casein layer due to casein degradation by hydrolysis (Fig. 4a). However, the MB4 protease did not function with $J$. curcas protein under the conditions tested, as shown by the absence of a clear zone formed in the $J$. curcas protein layer (Fig. 4b). Xylanase activity was found only in MB4 crude extract as shown by formation of a clear zone in RBB-xylan agar medium (Fig. 4c). Congo Red staining in $\mathrm{CMC}$ agar medium showed a negative result for glucanase activity in the crude extract of all strains tested (Fig. 4d). Figure 4d depicts that the enzyme GC-220 (Genencor Inc, USA) lacked glucanase activity as no clear zone formed in CMC agar medium.
Selection of paddy crab bacterial strain for Jatropha oil extraction

Figure 5 shows the amount of oil extracted from $12 \mathrm{~g}$ preheated Jatropha kernel slurry (containing 2 g kernel), inoculated with the isolated bacterial strains directly prepared by suspending the NA culture slant with $2 \mathrm{ml}$ water. We found that MB4 gave the highest Jatropha oil yield (63\%), a 15-fold increase compared to a control experiment containing antibiotics. MB4 was selected for further tests at different conditions of incubations.

\section{Identification of strain MB4}

The phenotypical characterization conducted by DSMZ (Germany) indicates that MB4 is a Bacillus pumilus strain (Table 1). The partial sequencing of 16S rDNA (data not shown) conducted also by DSMZ shows a similarity of $100 \%$ to Bacillus altitudinis and $99 \%$ to the type strain of B. pumilus. The partial sequence has been submitted to the GenBank (accession number HQ860795). Considering the result of the partial sequencing, a clear identification to species level is not possible. Further examinations will be required to find out the novelty of the strain MB4. The
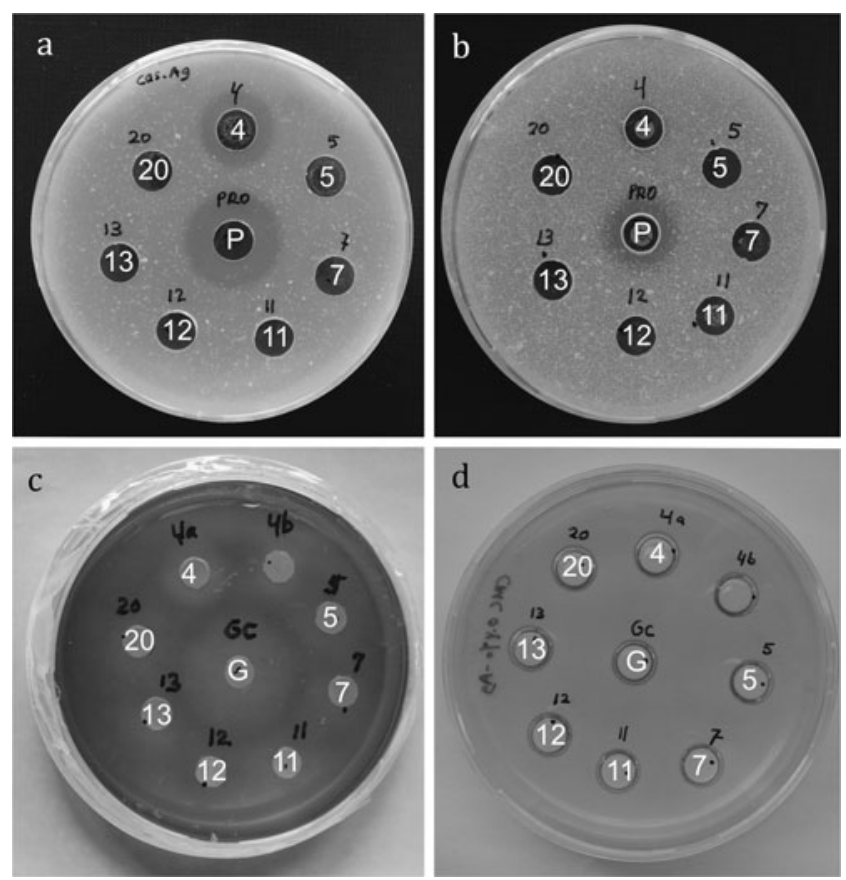

Fig. 4 Protease, xylanase, and glucanase activity of crude extracts of isolated bacterial strains on (a) casein agar plate, (b) Jatropha protein agar plate, (c) RBB-xylan agar plate, and (d) CMC agar plate. A 200x dilution of a protease, Protex $14 \mathrm{~L}(P)$ or a cellulase, GC-220 $(G)$ from Genencor was the positive control. Numbers on the plates denote the strain: 4, 5, 7, 11, 12, 13, and 20 for MB4, MB5, MB7, MB11, MB12, MB13, and MB20, respectively 


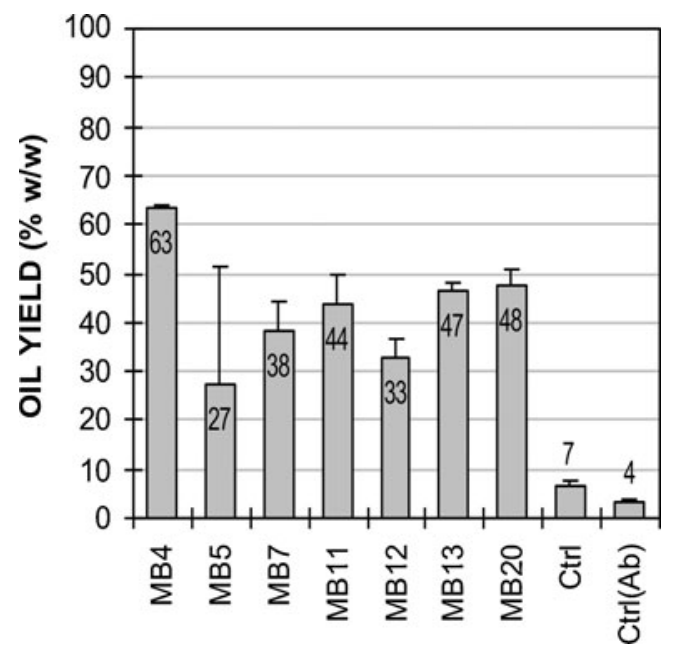

Fig. 5 Jatropha oil extraction yield from preheated kernel slurry after inoculation with different mesophilic bacterial strains from paddy crabs (MB4, MB5, MB7, MB11, MB12, MB13, and MB20) and incubated at $37^{\circ} \mathrm{C}, 150 \mathrm{rpm}$ for $24 \mathrm{~h}$

strain MB4 has been deposited in the DSMZ collection as DSM 24473 Bacillus sp. BioMcc B-0081

Microbial Jatropha oil extraction: optimization

The optimization of microbially assisted oil extraction was conducted in three steps. In first instance, we incubated preheated Jatropha kernel slurry with the starter culture of strain MB4 at $37^{\circ} \mathrm{C}$ over $24 \mathrm{~h}$ in order to find the optimum incubation time (Fig. 6a). Second, we studied the effect of initial $\mathrm{pH}(4.5,5.5,6.5,7.5$, and 8.5$)$ of the kernel slurry on oil liberation by strain MB4; kernel slurry $\mathrm{pH}$ was adjusted to the desired value by using $4 \mathrm{M}$ sodium hydroxide or $4 \mathrm{M}$ sulphuric acid solutions before inoculation of bacteria starter cultures (Fig. 6b). Third, we optimized incubation temperature $\left(37,45,50\right.$, and $55^{\circ} \mathrm{C}$ ) for Jatropha oil extraction (Fig. 6c).

Figure 6a shows that the oil yield in the control samples (containing antibiotics) remained below 10\% throughout incubation for $24 \mathrm{~h}$. The addition of MB4 starter culture to preheated kernel slurry resulted in a sharply increased oil yield to about $60 \%$ (tenfold increase compared to the control experiment) only within 6-8 h, after which it remained constant until $24 \mathrm{~h}$. Based on these results, we decided to shorten the incubation time to $6 \mathrm{~h}$ in the subsequent experiments of microbial-assisted oil extraction.

The oil yield of kernel slurry incubated with MB4 for $6 \mathrm{~h}$ at different $\mathrm{pH}$ values $(4.5,5.5,6.5,7.5$, and 8.5$)$ is shown in Fig. 6b. The oil yield of MB4-treated sample increased from $65 \%$ at $\mathrm{pH} 4.5$, to peak at $73 \%$ at $\mathrm{pH} 5.5$, and then decreased to $50 \%$ at $\mathrm{pH} 8.5$. Contrary to the curve trends obtained with MB4, the oil yield of control sample (containing antibiotics) decreased rapidly from $40 \%$ at
Table 1 Phenotypical characteristics of strain MB4

\begin{tabular}{|c|c|}
\hline Observed item & Result \\
\hline Shape of cells & Rods \\
\hline Width $(\mu \mathrm{m})$ & $0.6-0.7$ \\
\hline Length $(\mu \mathrm{m})$ & $2.0-3.0$ \\
\hline Aminopeptidase test & - \\
\hline $\mathrm{KOH}$ test & - \\
\hline Catalase & + \\
\hline Spores & Oval+ \\
\hline Sporangium swollen & - \\
\hline Anaerobic growth & + \\
\hline VP reaction & + \\
\hline $\mathrm{pH}$ in VP & 4.9 \\
\hline Growth temperature positive up to & $50{ }^{\circ} \mathrm{C}$ \\
\hline \multicolumn{2}{|l|}{ Growth in } \\
\hline Medium pH 5.7 & + \\
\hline $\mathrm{NaCl} 2 \%$ & + \\
\hline $\mathrm{NaCl} 7 \%$ & + \\
\hline $\mathrm{NaCl} 10 \%$ & + \\
\hline Lysozym $0.001 \%$ & + \\
\hline \multicolumn{2}{|l|}{ Acid from } \\
\hline D-Glucose & + \\
\hline D-Fructose & + \\
\hline D-Xylose & + \\
\hline D-Mannitol & + \\
\hline L-Arabinose & + \\
\hline Gas from D-Glucose & - \\
\hline \multicolumn{2}{|l|}{ Hydrolysis of } \\
\hline Starch & - \\
\hline Gelatin & + \\
\hline Casein & + \\
\hline Tween 80 & + \\
\hline Esculine & + \\
\hline Lechitinase & + \\
\hline Tyrosin degradation & - \\
\hline Indol reaction & - \\
\hline \multicolumn{2}{|l|}{ Use of } \\
\hline Citrate & + \\
\hline Propionate & - \\
\hline Phenylalanine deaminase & - \\
\hline Nitrate reduction & - \\
\hline Arginine dihydrolase & - \\
\hline
\end{tabular}

pH 4.5 to $10 \%$ at $\mathrm{pH} 5.5$, and then increased to $20 \%$ at $\mathrm{pH}$ 8.5. As a conclusion, strain MB4 has an optimum initial $\mathrm{pH}$ of 5.5 at $37{ }^{\circ} \mathrm{C}$. Based on these results, we therefore studied the effect of incubation temperature on oil liberation by MB4 at $\mathrm{pH} 5.5$ for $6 \mathrm{~h}$.

The oil yield from kernel slurry incubated with strain MB4 for $6 \mathrm{~h}$ at $\mathrm{pH} 5.5$ and different temperatures is shown 

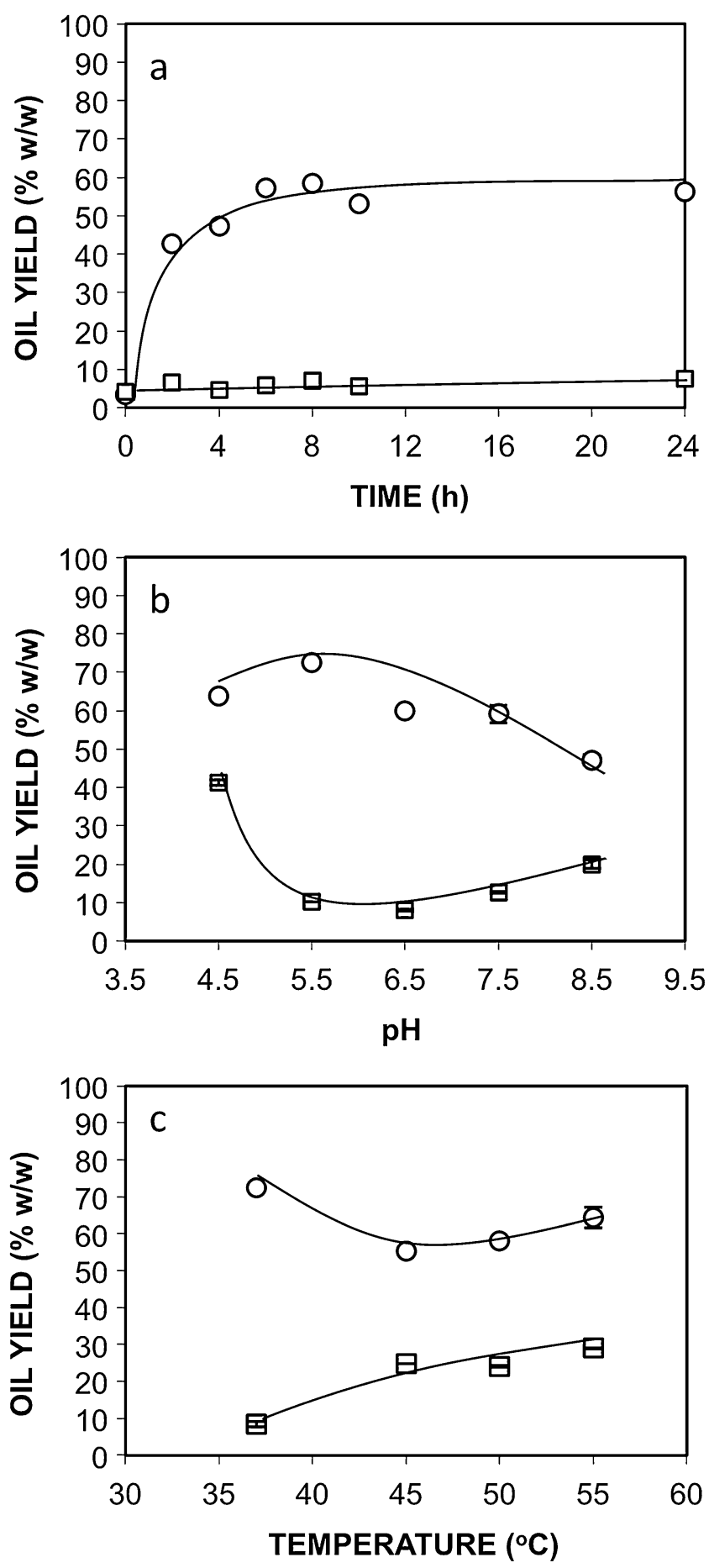

Fig. 6 Incubation of preheated Jatropha kernel slurry with MB4 (white circle) and without MB4 (white square): (a) oil extraction yield after incubation $\left(37^{\circ} \mathrm{C}\right.$ for $\left.24 \mathrm{~h}\right)$, the initial $\mathrm{pH}$ was not adjusted; (b) oil extraction yield after incubation at different initial $\mathrm{pH}\left(37^{\circ} \mathrm{C}\right.$ for $6 \mathrm{~h}$ ); and (c) oil extraction yield after incubation at $\mathrm{pH} 5.5$ at different temperatures $\left(37,45,50\right.$, and $55^{\circ} \mathrm{C}$ for $\left.6 \mathrm{~h}\right)$

in Fig. 6c. It is evident that the highest extraction yield of $73 \%$ was obtained at an incubation temperature of $37{ }^{\circ} \mathrm{C}$. The oil yield of MB4-treated sample decreased from $73 \%$ to $60 \%$ as the temperature increased from $37{ }^{\circ} \mathrm{C}$ to $45{ }^{\circ} \mathrm{C}$.
The oil yield of MB4-treated sample slightly increased to $64 \%$ when the temperature increased from $45^{\circ} \mathrm{C}$ to $55^{\circ} \mathrm{C}$. The oil yield of the control sample showed a slow increasing trend from $10 \%\left(37{ }^{\circ} \mathrm{C}\right)$, reaching a maximum oil yield of $30 \%$ only at $55{ }^{\circ} \mathrm{C}$. This slow increase can at least partially explain the increasing trend of oil liberation in the MB4-treated sample at temperature in the $45-55^{\circ} \mathrm{C}$ range.

Evaluation of protein integrity after microbial oil extraction

We investigated the molecular weight distribution of protein in liquid phase (supernatant) and solid phase (cake) after MB4 oil extraction, in comparison to those extracted with $0.055 \mathrm{M} \mathrm{NaOH}$, by using SDS-PAGE analysis as shown in Fig. 7. We did not recover protein in the interfacial phase for SDS-PAGE analysis because we observed a very low amount of solid in the interfacial phase (between oil-water) after centrifugation, indicating a lower amount of oil-water emulsion after MB4 treatment.

Figure 7 shows that almost all proteins in the range of 1.0 to $88.5 \mathrm{kDa}$ available in $0.055 \mathrm{M} \mathrm{NaOH}$-extracted sample were also available in the solid phase, with the exception of one protein $(88.5 \mathrm{kDa})$ that was missing in the solid phase. Three additonal proteins of 14.7, 27.4, and $44.9 \mathrm{kDa}$ that were not available in $\mathrm{NaOH}$-extracted sample were found in the solid phase as well as in the liquid phase. Six proteins of $1.7,8.5,9.4,10.6,11.3$, and $32.1 \mathrm{kDa}$ that

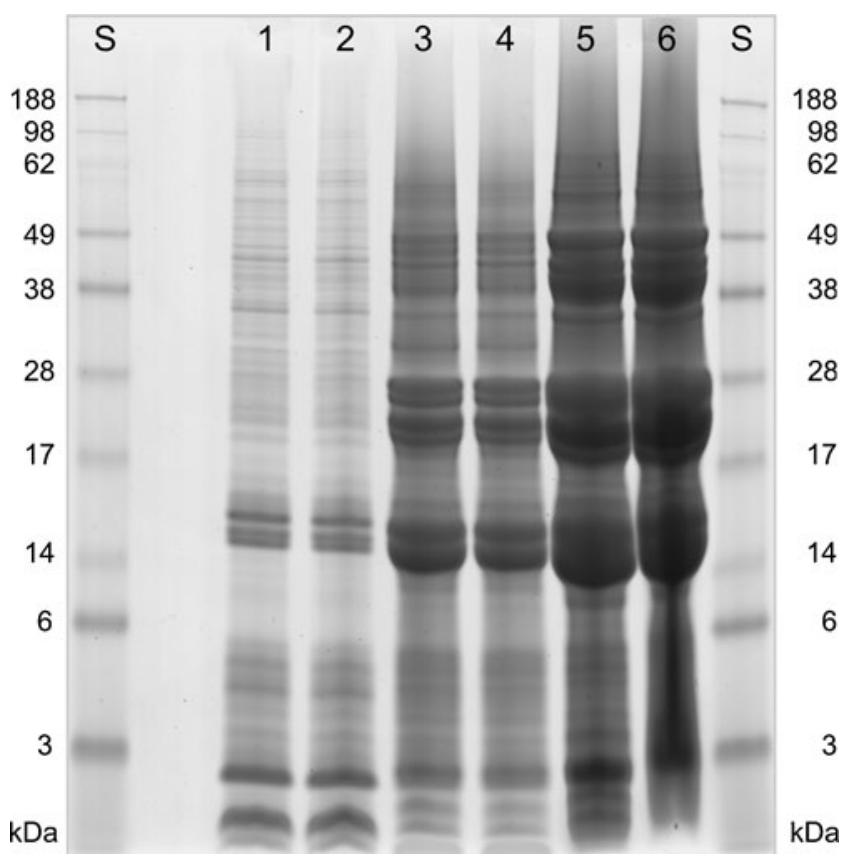

Fig. 7 SDS-PAGE analysis of MB4-treated Jatropha kernel proteins. Bands of proteins from duplicated samples of water phase (1 and 2), solid phase/cake (3 and 4) in comparison to Jatropha protein (5 and 6 ). $S$ stands for standard of protein marker 
were available in $\mathrm{NaOH}$-extracted sample were not detected in the liquid phase. Furthermore, 13 additional proteins of 2.8 , 11.9, 13.5, 14.7, 20.1, 25.1, 27.4, 29.2, 41.3, 44.9, 59.3, 100.1, and 130.4 that were not available in $\mathrm{NaOH}$-extracted sample were found in the liquid phase.

The quality of oil after aqueous oil extraction

Oil quality data in Table 2 show that the oil obtained by MB4 extraction, in general, meet the German fuel standard DIN V 51605 for pure plant oil (rapeseed oil), except for the acid value $(\mathrm{AV})$ which was found 8.6, or more than eight times higher than the standard value.

\section{Discussion}

$J$. curcas seed kernels have a high fat and protein content ranging between $45 \%$ and $55 \% \mathrm{w} / \mathrm{w}$ and $20-30 \% \mathrm{w} / \mathrm{w}$, respectively (Gubitz et al. 1999; Lestari et al. 2010). The oil is investigated for its suitability as a biofuel, whereas the protein has been extensively studied for food and non-food application (Gubitz et al. 1999; Lestari et al. 2010; Lin et al. 2003; Martinez-Herrera et al. 2006). Therefore, with respect to the overall economy of Jatropha cultivation, it is important to find commercial outlets for both oil and protein.

In studying the effect of heat pretreatment on protein integrity, we found proteins resolution on electrophoresis gel gave identical band positions among non-heated, preheated at $105{ }^{\circ} \mathrm{C}$ for $30 \mathrm{~min}$, and preheated at $121{ }^{\circ} \mathrm{C}$ for $30 \mathrm{~min}$ (Fig. 2). This means that the structure of Jatropha protein exhibits high thermal stability against thermal processing upon heating up to $121{ }^{\circ} \mathrm{C}$ for $30 \mathrm{~min}$. Thermal properties of proteins are important to study the changes during heat processing which, in turn, are useful in the processing designs for protein-based products (Horax et al. 2011).

Aqueous extraction is necessary for the recovery of the protein from the kernel, and in order to decrease process costs it is therefore interesting to liberate the oil from the seed in the same step. In protease-assisted aqueous oil extraction from oilseeds, oil-bound proteins are hydrolyzed into smaller fractions, thereby altering their structure and functionality (Moure et al. 2006). Similar studies in Jatropha oil extraction reported previously did not highlight the importance of preserving protein structure during oil extraction process. If the protein structures are to be conserved to a large extent in the recovery of oil from oilseeds, the use of bacterial strains or enzymes liberating oil by other means than protein solubilisation is a reasonable choice.

Apart from proteases, a number of microbial enzymes have been studied to enhance oil extraction yields from oilseeds: amylase, glucanase, pectinase, cellulolytic, and hemicellulolytic enzymes (Dominguez et al. 1994). We were therefore interested to isolate and select other microbial strains from the crab's gut capable of assisting oil liberation without degrading protein.

The paste of paddy fields crabs are traditionally used for coconut oil extraction in Java. In a previous article, we have also applied paste crab to release oil from Jatropha kernels (Marasabessy et al. 2010). Whereas we now were able to release $70 \%$ of the oil, we previously only liberated $30 \%$ of the oil. Even though the experimental conditions in using paddy crab paste as the research material between the present study and the previous study (Marasabessy et al. 2010) look similar, they are not entirely the same for two reasons. First, in our present study, preheated kernels were used as substrate instead of non-heated kernel used in the previous study. Preheating the kernels might have enhanced the dissolution of cell components which were previously bound to the original structures of cells (Williams 2005), allowing crab's enzymes or microbial enzymes to have access in breaking oil barriers, resulting in the release of more oil as compared to control experiments (Fig. 3). Second, the different batch of crab paste used in the present study might have resulted in differences in oil liberation.

We found that MB4 starter culture was able to extract $73 \%$ oil from Jatropha kernel slurry when incubated for $6 \mathrm{~h}$ at $37{ }^{\circ} \mathrm{C}$ and $\mathrm{pH}$ 5.5. This is in good agreement with the Jatropha oil yield of $85.6 \%$ and $74 \%$ extracted by using
Table 2 The quality of oil extracted from Jatropha kernel using MB4 bacterial strain (AOE-MB4) compared to that extracted by expeller and the standard values

\footnotetext{
$O S I$ oxidative stability index, $A V$ acid value

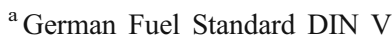
51605
}

\begin{tabular}{llll}
\hline Parameters & \multicolumn{2}{l}{ Methods and oil quality } & Standard value $^{\mathrm{a}}$ \\
\cline { 2 - 3 } & AOE-MB4 & Expeller & \\
\hline Seeds source & J. curcas & J. curcas & - \\
Feed type & Preheated kernels & Whole seeds & - \\
Expeller type & - & De-Smet UK & - \\
Conditions & $6 \mathrm{~h}, 150 \mathrm{rpm}, 37^{\circ} \mathrm{C}$ & $25 \mathrm{rpm}, 80-85^{\circ} \mathrm{C}$ & - \\
OSI (h) & $7.8 \pm 0.06$ & 10.7 & Min 6 \\
AV (mg KOH/g oil) & $8.6 \pm 0.20$ & 10.3 & Max 2 \\
Water (mppm) & $719 \pm 32$ & 1147 & Max 750 \\
\hline
\end{tabular}


protease of Alcalase (Novo Nordisk, Denmark) and Protizyme (Jaysons Agritech, India), respectively (Shah et al. 2005; Winkler et al. 1997). The use of Viscozyme (Novo Nordisk, Denmark) as a hemicellulase/cellulase formula gave a comparable oil yield of $70 \%$ (Winkler et al. 1997).

We have shown that protease from strain MB4 bears no activity against Jatropha protein. Hence, by considering the optimal $\mathrm{pH}$ and temperature of MB4 $\left(\mathrm{pH} 5.5\right.$ and $37{ }^{\circ} \mathrm{C}$, respectively) and also the presence of xylanase in the crude extract of MB4, it is most likely that the strain MB4 facilitates oil liberation at $37{ }^{\circ} \mathrm{C}$ via the degradation of hemicellulose that forms the oil-containing cell wall structure of the kernel (Rosenthal et al. 1996).

Bacterial identification results suggested the strain MB4 as $B$. pumilus or the closely related B. altitudinis. In case of $B$. pumilus, previous investigations have reported the potential application of $B$. pumilus as xylanase producer (Ahlawat et al. 2007; Battan et al. 2007; Kapoor and Kuhad 2007; Kapoor et al. 2008; Nagar et al. 2010; Wang et al. 2010; Yasinok et al. 2010). In contrast, we found that only a few publications are available on the potential application of $B$. altitudinis.

After MB4-assisted oil extraction, the extracted oil has an $\mathrm{AV}$ below 14\% (Table 2), which seems applicable for biodiesel production since a chemical pretreatment to reduce the acid value from $14 \%$ to $1 \%$ before transesterification of Jatropha oil into biodiesel has been established recently, which results $99 \%$ yield of biodiesel (Tiwari et al. 2007).

Concluding, strain MB4 identified as B. pumilus or $B$. altitudinis isolated from paddy crab liberated $73 \% w / w$ of Jatropha oil from preheated kernel in aqueous system after $6 \mathrm{~h}$ incubation at $37^{\circ} \mathrm{C}$. It is suggested that the strain MB4 facilitates oil liberation via degradation of hemicellulose. Incubation of $J$. curcas kernel with strain MB4 preserves the Jatropha protein structure to a large extent. MB4assisted oil extraction has several advantages: (a) no purified cocktail enzyme preparation is required, (b) protein integrity is mostly preserved, and (c) this method results in Jatropha oil with a quality which is suitable for biodiesel production.

Acknowledgments The authors gratefully acknowledge the Koninklijke Nederlandse Akademie van Wetenschappen, Scientific Programme Indonesia-Netherlands (SPIN-KNAW) for the financial assistance. We also would like to acknowledge Erna Subroto, $\mathrm{PhD}$ student at Rijks Universiteit Groningen the Netherlands for conducting oil quality analysis, and Dianika Lestari for her help in conducting gel electrophoresis of Jatropha protein of our samples.

Open Access This article is distributed under the terms of the Creative Commons Attribution Noncommercial License which permits any noncommercial use, distribution, and reproduction in any medium, provided the original author(s) and source are credited.

\section{References}

Ahlawat S, Battan B, Dhiman SS, Sharma J, Mandhan RP (2007) Production of thermostable pectinase and xylanase for their potential application in bleaching of kraft pulp. J Ind Microbiol Biotechnol 34:763-770

AOAC (1984) Official methods of analysis. AOAC Int

AOAC (2002) Official methods of analysis. AOAC Int Maryland, pp 69

Barrios VA, Olmos DA, Noyola RA, Lopez-munguia CA (1990) Optimization of an enzymatic process for coconut oil extraction. Oleagineux 45:35-42

Battan B, Sharma J, Dhiman SS, Kuhad RC (2007) Enhanced production of cellulase-free thermostable xylanase by Bacillus pumilus ASH and its potential application in paper industry. Enzyme Microb Technol 41:733-739

Caragay AB (1983) Pacing technologies in the fats and oils industry. J Am Oil Chem Soc 60:1641-1644

Dominguez H, Nunez MJ, Lema JM (1994) Enzymatic pretreatment to enhance oil extraction from fruits and oilseeds: a review. Food Chem 49:271-286

Gubitz GM, Mittelbach M, Trabi M (1999) Exploitation of the tropical oil seed plant Jatropha curcas L. Bioresour Technol 67:73-82

Horax R, Hettiarachchy N, Kannan A, Chen G (2011) Protein extraction optimisation, characterisation, and functionalities of protein isolate from bitter melon (Momordica charantia) seed. Food Chem 124:545-550

Kapoor M, Kuhad RC (2007) Immobilization of xylanase from Bacillus pumilus strain MK001 and its application in production of xylooligosaccharides. Appl Biochem Biotechnol 142:125-138

Kapoor M, Nair LM, Kuhad RC (2008) Cost-effective xylanase production from free and immobilized Bacillus pumilus strain MK001 and its application in saccharification of Prosopis juliflora. Biochem Eng J 38:88-97

Lestari D, Mulder W, Sanders J (2010) Improving Jatropha curcas seed protein recovery by using counter current multistage extraction. Biochem Eng J 50:16-23

Lin J, Yan F, Tang L, Chen F (2003) Antitumor effects of curcin from seeds of Jatropha curcas. Acta Pharmacol Sin 24:241-246

Marasabessy A, Moeis MR, Sanders JPM, Weusthuis RA (2010) Coconut oil extraction by the traditional Java method: an investigation of its potential application in aqueous Jatropha oil extraction. Biomass Bioenergy 34:1141-1148

Martinez-Herrera J, Siddhuraju P, Francis G, Davila-Ortiz G, Becker K (2006) Chemical composition, toxic/antimetabolic constituents, and effects of different treatments on their levels, in four provenances of Jatropha curcas L. from Mexico. Food Chem 96:80-89

Moure A, Sineiro J, Dominguez H, Parajo JC (2006) Functionality of oilseed protein products: a review. Food Res Int 39:945-963

Nagar S, Gupta VK, Kumar D, Kumar L, Kuhad RC (2010) Production and optimization of cellulase-free, alkali-stable xylanase by Bacillus pumilus SV-85S in submerged fermentation. $\mathrm{J}$ Ind Microbiol Biotechnol 37:71-83

Rosenthal A, Pyle DL, Niranjan K (1996) Aqueous and enzymatic processes for edible oil extraction. Enzyme Microb Technol 19:402-420

Shah S, Sharma A, Gupta MN (2005) Extraction of oil from Jatropha curcas L. seed kernels by combination of ultrasonication and aqueous enzymatic oil extraction. Bioresour Technol 96:121-123

Shuit SH, Lee KT, Kamaruddin AH, Yusup S (2010) Reactive extraction and in situ esterification of Jatropha curcas L. seeds for the production of biodiesel. Fuel 89:527-530

Strauss MLA, Jolly NP, Lambrechts MG, van Rensburg P (2001) Screening for the production of extracellular hydrolytic enzymes 
by non-Saccharomyces wine yeasts. J Appl Microbiol 91:182190

Teather RM, Wood PJ (1982) Use of congo red-polysaccharide interactions in enumeration and characterization of cellulolytic bacteria from the bovine rumen. Appl Environ Microbiol 43:777-780

Tiwari AK, Kumar A, Raheman H (2007) Biodiesel production from jatropha (Jatropha curcas) with high free fatty acids: an optimized process. Biomass Bioenergy 31:569-575

Wang J, Zhang WW, Liu JN, Cao YL, Bai XT, Gong YS, Cen PL, Yang MM (2010) An alkali-tolerant xylanase produced by the newly isolated alkaliphilic Bacillus pumilus from paper mill effluent. Molec Biol Reports 37:3297-3302
Williams MA (2005) Recovery of oils and fats from oilseeds and fatty materials. In: Shahidi F (ed) Bailey's industrial oil and fat products. Wiley, New Jersey, p 109

Winkler E, Foidl N, Gubitz GM, Staubmann R, Steiner W (1997) Enzyme-supported oil extraction from Jatropha curcas seeds. Appl Biochem Biotechnol 63-65:449-456

Yasinok AE, Biran S, Kocabas A, Bakir U (2010) Xylanase from a soil isolate, Bacillus pumilus: gene isolation, enzyme production, purification, characterization and one-step separation by aqueoustwo-phase system. World J Microbiol Biotechnol 26:1641-1652

Zeng JL, Wang XD, Zhao B, Sun JC, Wang YC (2009) Rapid in situ transesterification of sunflower oil. Ind Eng Chem Res 48:850 856 